\title{
AN ANALYSIS OF ENGLISH CODE MIXING USED IN INDONESIAN MAGAZINE
}

\author{
${ }^{1,2}$ Syafryadin \& ${ }^{1}$ Haryani \\ ${ }^{1}$ English Language Education, University of Bengkulu, Indonesia \\ ${ }^{2}$ Corresponding Author email: syafryadin@unib.ac.id
}

\begin{tabular}{l}
\hline \hline Article Info \\
\hline Article History \\
Received: March 2020 \\
Revised: April 2020 \\
Published: October 2020
\end{tabular}

Keywords

Code Mixing Type;

Teenage magazine;

\begin{abstract}
This study investigated the types of code mixing used in one of teenage magazines in Indonesia, namely Aneka Yess! magazine. The research question was "what types of code mixing used in Aneka Yess! magazine”. The objective of this study was to find out the types of code mixing used in Aneka Yess! magazine, especially in "Palls Issue" rubric. The design of this study was descriptive qualitative. The techniques of data collection were: 1) collected the magazine during a month which consisted of two editions, namely $14-27$ March dition, and 28 March10 April edition, 2) decided the rubric as an object of the study, 3) read the rubric, 4) underlined English code mixings, 5) identified the forms of code mixing. The result of this study showed that there were five forms of code mixings that used in the magazine, namely code mixing of word insertion that consist of 64 data, phrase insertion consist of 29 data, clause insertion consist of 10 data, reduplication insertion consist of 1 data, and idiom insertion consist of 4 data. The code mixings in word insertion was most frequently used in the magazine rather than the other types of code mixings, while the most rarely used was code mixing in reduplication insertion. It can be concluded that the using of code mixing was influenced by the capability or the knowledge of the speaker or interlocutor in using English language.
\end{abstract}

How to cite: Syafryadin. (2020). An analysis of English code mixing used in Indonesian magazine. JOLLT Journal of Languages and Language Teaching, 8(4), 381-390, DOI: https://doi.org/10.33394/jollt.v\%vi\%i.2465

\section{INTRODUCTION}

Yee Ho (2007:1) states that code mixing is the change of one language to another within the same utterance or in same oral or written text. Code mixing in the written form can be found in texts such as newspaper, magazine, novel, article, etc. Aneka Yess! Magazine often gives information regarding Indonesian teenage artist lifestyle, in which teen issues are discussed by experts. There are many code mixing found in that magazine. For examples, "tapi nggak semua orang mengalami happy ending, kan?" (Aneka Yess! Magazine on 27 September - 10 October, p.76-77). As far as code mixing is concerned and some rationals above, the writer was interested in analyzing code mixing used in Aneka Yess! magazine. The research question of this study was, "What types of code mixing used in Aneka Yess! magazine?" The objective of this study was to find out and analyze the types of code mixing used in Aneka Yess! magazine. The scope of this study focused on the types of code mixing between Indonesian and English languages (which consist of code mixing on word insertion, phrase insertion, clause insertion, expression or idiom insertion, and reduplication insertion (Soewito, 1985:76) used in Aneka Yess! magazine in "pals issue" rubric).

Soewito (1985:76) and Callhavid (2010) stated that based on language elements, there are five kinds of code mixing which are (1) Word insertion: It means that code mixing occurred when a speaker speaks in a certain language but he or she inserts a word or a number of words of other language in one utterance. (2) Phrase insertion: It means that code mixing 
occurred when a speaker speaks in a certain language but he or she inserts a phrase of other language in one utterance. (3) Reduplication insertion: It means that code mixing occurred when a speaker speaks in a certain language but he or she inserts a reduplication of other language in one utterance. (4) Expression or idiom insertion: It means that code mixing occurred when a speaker speaks in a certain language but he or she inserts an expression or idiom of other language in one utterance. And (5) Clause insertion: It means that code mixing occurred when a speaker speaks in a certain language but he or she insert a clause of other language in one utterance.

Next, analyzing the code mixing through morphological, semantic, and syntactic analysis. In this case, morphology is the study of how words are structured and how they are put together from smaller parts (McManis, Stollenwerk, and Sheng, 1987:117). Hartini (2010:22) defines that syntactic analysis is used to generalize whether a data of code mixing in clause insertion fulfills a minimal characteristic of a clause or a sentence elements that consists of subject and predicate or not. Syntactically, subject and predicate are the two main functional categories in a sentence. (Thomas, 1993:15). Semantic is a study of meaning. As denoted by Dijk (1985:104) that a semantic theory is the concept of interpretation.

Several previous studies conducted the research on code mixing, however, the previous studies always made the research not only code mixing, but also code switching. Previous studies were about the types of code mixing, code switching, and the factors of using code mixing. Firstly, Ansar (2017) and Mustikawati (2018) conducted studies aimed to describe the factors of deciding form of code switching and code-mixing specific form in learning activities. The findings showed the code-mixing deciding factor in the learning process were role, desire to explain and interpret, sourced from original language and variation, while for code switching process were speakers, partner speakers and the topic of conversation.

This research was almost the same as Mukti and Muljani (2016) and Yuliana, Luziana \& Sarwendah (2015), but Mukti and Mulyani only used code switching in the teaching and learning activities, while Yuliana et al. (2015) studied on code switching and code mixing in Indonesian celebrities. Similar research also done by Syafrizal \& Sari (2017) and Siregar, Rasyidah and Niati (2016) where their research aimed to know why did the students use code mixing on Twitter and Facebook status, the factors that influence the students did it and the code mixing types. Bar and Hossain (2015), Astuti (2017) and Suparti \& Gunawan (2018) also conducted the research which aimed to know the levels of code mixing and the factors. In brief, those previous studies, were about code mixing, however the object of the research was different, namely in teaching and learning activities, novel, student' conversation, Facebook and Twitter posts and celebrities. However, the current research had intention to do research on code mixing, but the media or source was different. I.e. magazine.

The research question of this study is what types of code-mixing used in one of teenage magazines in Indonesia, namely Aneka Yess! magazine. Code-mixing concepts are very interesting to be applied in this study to see the types of code-mixing used by the writer. The result of this analysis can be useful for discourse analysis aspects for further studies on it.

\section{RESEARCH METHOD Research Design}

The design of this study was descriptive qualitative. Descriptive qualitative was a research qualitative which also suitable for the research questions which emphasized on what, who and where of the experiences (Nergaard, et al. 2009; Sulivan, et al. 2005) Besides, Sugiyono (2009) stated that descriptive qualitative was a research which produced the descriptive data either spoken or written. This research used descriptive qualitative because 
this research aimed to know the types of code mixing existed in the magazine. It meant that it focused on the research question of "what" to get the information related to the events.

\section{Source of the Data}

The data of this study were written language in Indonesian teen magazine (Aneka Yess!). The publisher of the magazine was Gramedia Digital Indonesia which located in Jakarta. This magazine was published in online and printed. The magazines were collected during a month consisted of two editions, i.e. 14 - 27 March edition and 28 March - 10 April edition. The data were categorized based on the types of code mixing, such, word insertion, phrase, clause, idiom and reduplication.

\section{Procedure of Data Collection}

The procedure of collecting the data was adapted from Sugiyono (2009). The procedure includes (1) collecting the magazine during a month which consisted of two editions, namely 14 - 27 March edition, and 28 March - 10 April 2017 edition; (2) Deciding and reading the rubric as an object of the study; Underlining the English code mixing; and Indentifying the types of code mixing.

\section{Technique of Data Analysis}

The gathered data analyzed by using morphological, semantic, and syntactic approach through the following steps: (1) Doing classification of the data based on the types of code mixing in terms of word, phrase, clause, idiom, and reduplication insertion. And (2) making description and generalization of every data in terms of types of English code mixing happened in Indonesian sentences (Adapted from McManis, Stollenwerk, and Sheng, 1987:117).

\section{RESEARCH FINDINGS AND DISCUSSION}

The research findings relate to the objective of this study which focused on the types of code mixing in teenage magazine. The types of code-mixing used in this magazine can be as consideration for teachers and learners to acquire language inputs and language practice in using authentic communication. The general theory of code mixing refers to Soewito (1985:76) and Callhavid (2010). The findings of this research showed that there were five types of code mixing found in the magazine, such as word insertion, phrase insertion, clause insertion, idiom and reduplication. For more detail findings are described in table 1, 2, 3, 4, and 5.

\section{Code Mixing of Word Insertion}

Table 1.

Word insertion

\begin{tabular}{ll}
\hline No & Word Insertion \\
\hline 1 & "Sudah ngerasa passion kita di suatu bidang tertentu." \\
\hline 2 & ...ambil jurusan terkait untuk mengasah skill kita. \\
\hline 3 & $\ldots$, dan sudah sering mendesain dengan guide dari buku. \\
\hline 4 & Well ...perlu pertimbangan cermat buat menentukannya. \\
\hline 5 & ...kita yang sudah menyusun secara detail mau dibawa kemana masa depan kita. \\
\hline
\end{tabular}




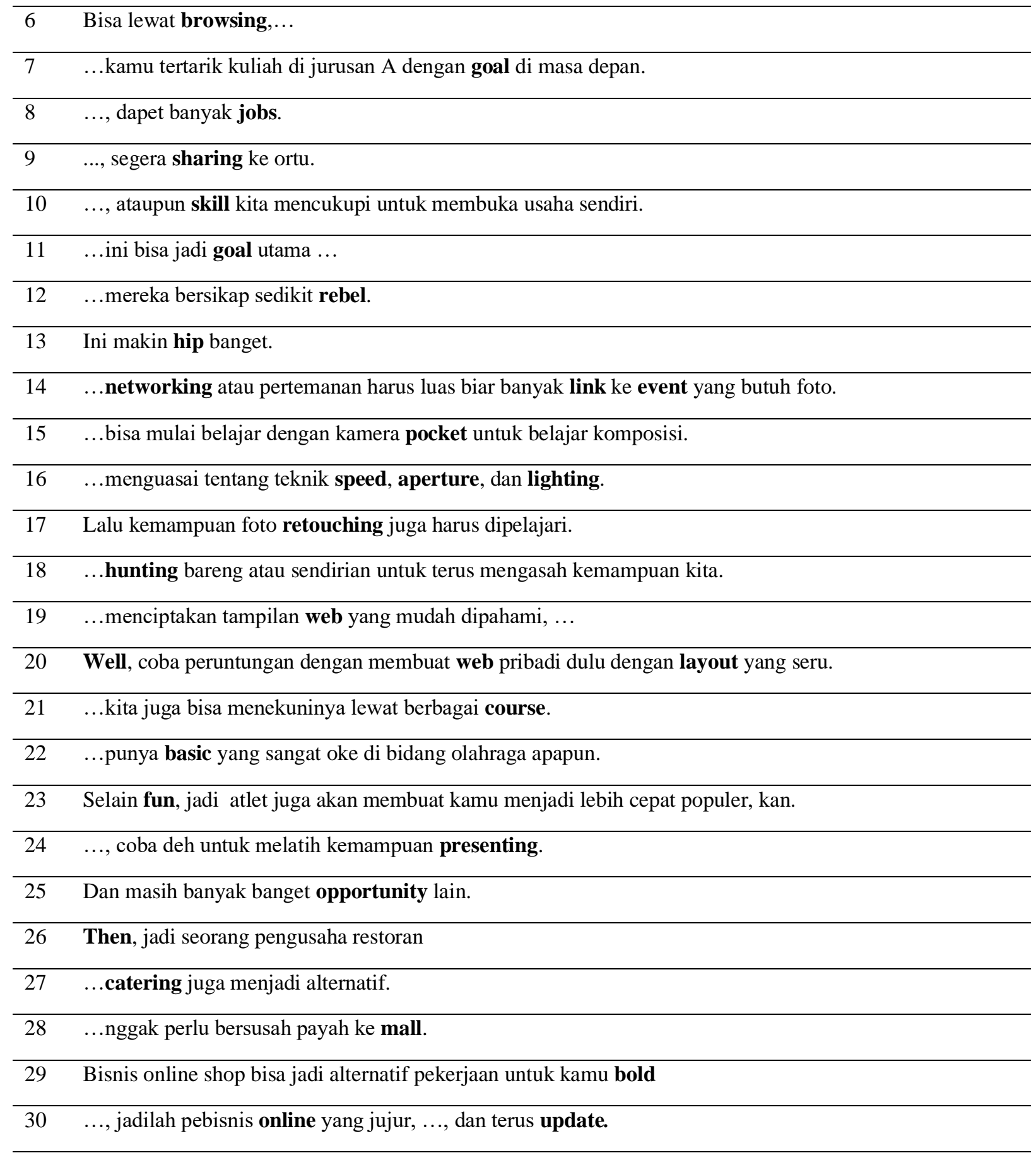

\section{Word Insertion}

31 Yup!..sekarang memang saatnya...untuk menyiapkan diri buat ujian.

32 Nah, Pals Issue kali ini special ...

33 Relax aja, tetap bertanggung jawab,...

34 Well, kita akan sering ketemu dengan murid lain

$35 \quad \ldots$, plus bisa dapat trik belajar dari mereka juga.

36 Musik slow akan pas untuk pelajaran hafalan

37 Kopi memang men-suggest seseorang biar nggak ngantuk. 

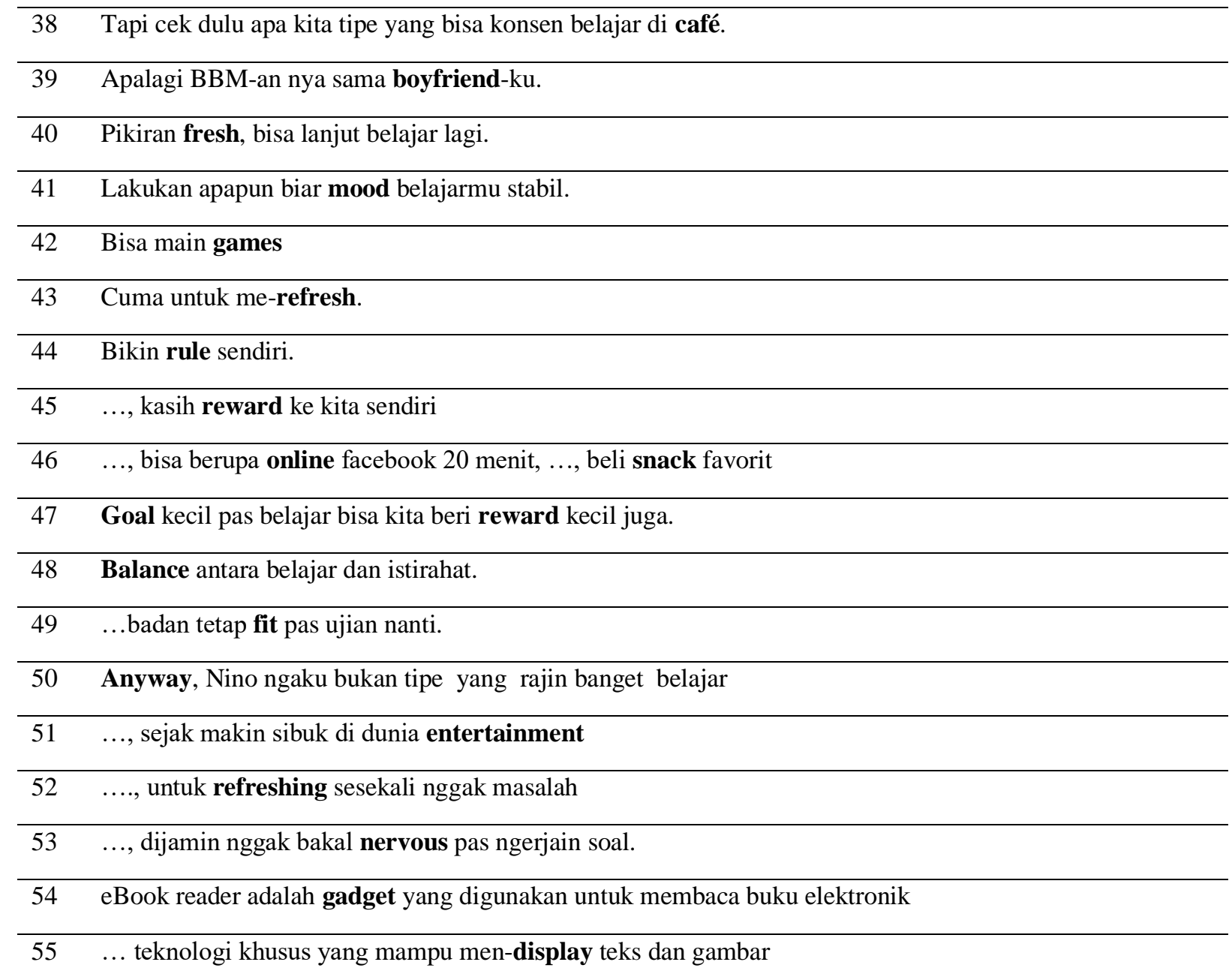

56 Website ini jadi komunikatif banget karena kita bisa sekalian ngobrol dengan browser yang lain.

$57 \quad$....kita ingin translate, dengan SuperPen kita hanya tinggal scan kata yang ingin diterjemahkan.

$58 \quad$...speaker Gigiway Pen ngeluarin melodi sesuai not balok yang di-scan

$59 \quad$..., kabarnya banyak musisi professional dilibatkan.

$60 \quad \ldots$, salah satu cara yang fun buat lebih mengerti sejarah

$61 \quad$ Kamu bisa search di www.komunitashistoria.org

$62 \quad$ Atau ke sang founder

63 Actually, ... mereka concern terhadap generasi muda

64 Di sini kita nggak cuma belajar secara teks book,...

There were 64 data that related to word insertion found. In this case, the code mixing of word insertion can be analyzed by using morphological and semantic approach. One of the examples as follows:

1) ...menguasai tentang teknik speed, aperture, dan lighting.

Morphologically, the word "lighting" consists of two morphemes namely the word "light" and suffix "-ing". The word "light" is a free morpheme because it can stand alone as word, while suffix "-ing" is a bound morpheme since it always attached to other morpheme. In this case, the morphological process of the word "light" becomes "lighting" is called as 
inflectional morpheme because the attachment of suffix "-ing" does not change its word class (light vs. lighting, both nouns). While the words "speed" and "aperture" are free morphemes because those words can stand alone without any attachment of prefix or suffix.

Semantically, the word "speed" means the rate at which something moves or travels. While the word "aperture" means the size of the hole of camera through which light passes to reach the film, and the word "lighting" signified as the use of different electric lights to give a particular effect.

\section{Code Mixing of Phrase Insertion}

Table 2.

Phrase insertion

\begin{tabular}{ll}
\hline No & \multicolumn{1}{c}{$\begin{array}{c}\text { Phrase Insertion } \\
\text { (March } \mathbf{1 4}^{\text {th }}-\mathbf{M a r c h ~} \mathbf{2 7}^{\text {th }} \text { Edition (page 83-87)) }\end{array}$} \\
\hline 1 & $\ldots$, makanya kita pengen banget bisa jadi graphic designer \\
\hline 2 & ...buat yang masih bingung menentukan future career \\
\hline 3 & ....jurusan kuliah yang mungkin tepat adalah public relations \\
\hline 4 & Thank God, kalau ternyata kita besar di tengah keluarga yang demokratis. \\
\hline 5 & Bisa jadi backup plan dan bukan nggak mungkin bikin masa depan kita lebih sukses \\
\hline 6 & ...that's why kita perlu memperkaya wawasan \\
\hline 7 & Beberapa cool jobs ini bisa jadi goal utama ..., atau bisa dijadikan back up \\
\hline 8 & The point is, jurusan kuliah yang nantinya kita pilih masih bisa kita kembangin \\
\hline 9 & ...itu berarti mereka punya alternative solution kalau one day ada masalah \\
\hline 10 & ... jasa web designer untuk menciptakan tampilan web \\
\hline 11 & Kemampuan public speaking akan dibutuhkan banget \\
\hline 12 & Misalnya jadi radio announcer
\end{tabular}

\section{Phrase Insertion
$\left(\left(28^{\text {th }}\right.\right.$ of March $-10^{\text {th }}$ of April Edition (page 88-94))}

\begin{tabular}{ll}
\hline 16 & Happy studying...!...sekarang memang saatnya...untuk menyiapkan diri \\
\hline 17 & $\ldots$ kali ini special ngebahas berbagai study tricks. \\
\hline 18 & Relax aja, tetap bertanggung jawab, and play hard! \\
\hline 19 & ...waktu masih sangat remaja saya lebih ada di sisi play hard ketimbang study hard. \\
\hline 20 & Musik up-beats akan pas untuk pelajaran hitungan \\
\hline 21 & Bisa dengan ngerayain bareng teman, atau cara have fun lainnya \\
\hline 22 & Tapi mereka punya special tricks biar ujian bisa dilewati dengan mulus.
\end{tabular}




\begin{tabular}{ll}
\hline 23 & Belajar di library café. \\
\hline 24 & ...yang terpenting menjelang ujian adalah kurangi waktu main games dan hang out. \\
\hline 25 & ... Kevin nyaranin belajar di coffee shop atau library café. \\
\hline 26 & eBook reader adalah gadget yang digunakan untuk membaca buku elektronik \\
\hline 27 & Siapa bilang belajar sejarah itu super boring? \\
\hline 28 & Belajar bareng teman lewat video conference lewat web cam \\
\hline 29 & Tapi justru di last minute kayak gitu, pelajaran bisa cepet masuk semua. \\
\hline 30 & Karena di sekolahku sistemnya moving class \\
\hline
\end{tabular}

There were 29 data that related to phrase insertion. In this case, one of the examples in analyzing it as follows:

2) ...buat yang masih bingung menentukan future career

Based on the data above, it was called as code mixing on phrase insertion of English phrase "future career" into Indonesian sentence. Morphologically, the phrase "future career" is a phrase that consists of two words or morphemes namely "future" and "career". The word "future" and "career" are free morphemes because those words can stand alone without any attachment of prefix or suffix. The phrase "future career" categorized as a noun phrase. Semantically, "future career" indicates the job or profession that someone will get in the future.

\section{Code Mixing of Clause Insertion}

Table 3.

Clause insertion

\begin{tabular}{|c|c|}
\hline No & $\begin{array}{c}\text { Clause Insertion } \\
\left(\text { March } 14^{\text {th }}-\text { March } 27^{\text {th }} \text { Edition (page 83-87)) }\right.\end{array}$ \\
\hline 1 & Beruntung kalau kita termasuk sudah know what I want to be sejak sekarang. \\
\hline 2 & Makanya Pals Issue kali ini hopefully will help you to find it. \\
\hline 3 & $\begin{array}{l}\text { Thank God, kalau ternyata kita besar di tengah keluarga yang demokratis. But the problem is when } \\
\text { there is an intervention by the parent. }\end{array}$ \\
\hline 4 & Finally, the rest is yours. Kalau masih belum yakin segera sharing ke ortu \\
\hline 5 & $\begin{array}{l}\text {... kalau pekerjaan...yang kita pilih ternyata nggak bisa didapetin. So, find the answer here and be alert } \\
\text { to every possibility. }\end{array}$ \\
\hline 6 & $\begin{array}{l}\text {...kesempatan novel kamu difilmkan, tentunya uang tabungan kamu akan segera melismpah. So, start } \\
\text { writing anything right now. }\end{array}$ \\
\hline
\end{tabular}

\section{Clause Insertion \\ ((28 ${ }^{\text {th }}$ of March $-10^{\text {th }}$ of April Edition (page 88-94))}

7 Jangan bilang nggak bisa atau nggak mampu dahulu sebelum mencobanya. So, be positive and act positive, right now! 


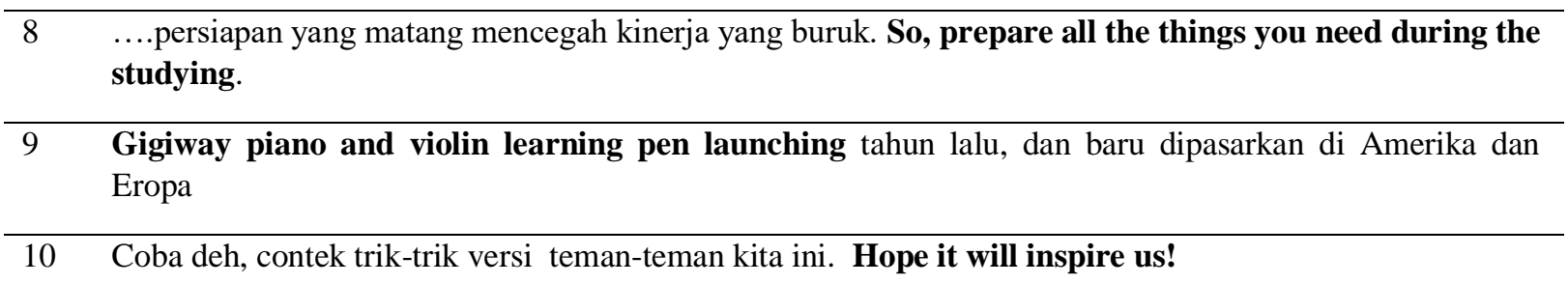

There are 10 data only that indicate code mixing on clause insertion found in this study. The data could be analyzed as follows:

3) Makanya Pals Issue kali ini hopefully will help you to find it.

Based on the data above, it was called as code mixing on clause insertion of English clause "hopefully will help you to find it" into Indonesian sentence. Syntactically, the sentence "palls issue...hopefully will help you to find it" categorized as a clause because it can fulfill a minimal aspect of a sentence, they are subject and predicate. In the clause, palls issue is a subject and hopefully will help you to find it is predicate. This clause is categorized as dependent clause because it cannot stand independently by itself and become a complete sentence.

\section{Code Mixing of Expression or Idiom Insertion}

Table 4.

Idiom/expression insertion

\begin{tabular}{lc}
\hline No & $\begin{array}{c}\text { Idiom/Expression Insertion } \\
\left(\text { March } 14^{\text {th }}-{\text { March } 27^{\text {th }}}_{(\text {page } 83-87))}\right.\end{array}$ \\
\hline 1 & Open minded. Siap menerima kritik dan saran, baik dari ortu ataupun guru-guru di sekolah \\
\hline 2 & $\ldots$. membuat web pribadi dulu dengan layout yang seru dan out of the box \\
\hline
\end{tabular}

\section{Idiom/expression Insertion \\ ( $\left(28^{\text {th }}\right.$ of March $-\mathbf{1 0}^{\text {th }}$ of April 2012 Edition (page 88-94))}
3 ...di bulan-bulan seperti sekarang memang saatnya "take a deep breath" untuk menyiapkan diri buat ujian.
4 Pemahaman tetep cara terbaik. The more you understand, the less you have to remember.

There are 4 data only that indicate code mixing on expression or idiom insertion found in this study. The every data are analyzed as follows:

\section{4) Open minded}

Based on the data above, it was called as code mixing on idiom insertion of English idiom "open minded" into Indonesian sentence. In this case, "open minded" defined as idiom because it is has different meaning from the meaning of all individual words. It means that, the idiom "open minded" is a group of words which has a different meaning when used together from the one they would have if we took the meaning of each word separately. Semantically, the idiom "open minded" means that someone who is willing to listen to and consider other people's ideas and suggestions. 


\section{Code Mixing of Reduplication Insertion}

Table 5.

Phrase insertion

\begin{tabular}{lc}
\hline No & Reduplication Insertion \\
& (March 14
\end{tabular}

1 Siapa tahu bisa chit-chat sama pakar fisika terkemuka.

The data above could be analyzed below:

5) Siapa tahu bisa chit-chat sama pakar fisika terkemuka.

Based on the data above, the writer categorizes the code mixing that happened in the sentence is code mixing on reduplication insertion of English reduplication "chit-chat" into Indonesian sentence. In the sentence, there is a repetition of the base word "chit" become "chit-chat". Semantically, the word "chit-chat" means an informal talk about something in a friendly way.

The findings of this study just identified the types of code mixing in magazine. Five forms existed in the magazine namely word insertion, phrase insertion, reduplication, idiom and clause insertion. This finding was based on the theory from Soewito (1985:76). There were 64 word insertions, 30 phrases insertions, 10 clause insertion, 4 idioms insertion and 1 reduplication insertions. The dominant code mixing type occurred in the magazine was 64 word insertions, while the minority code mixing type was reduplication. The previous studies from Syafrizal \& Sari (2017) and Siregar, Rasyidah and Niati (2016) confirmed the dominant types were word insertions. The objects of their research were different from this current research, but the result of the code mixing types was the same. This was caused the word is the smaller element than the phrase and many people used word to do code mixing whether in written form or oral form. Reduplication is the minority in this current research because in magazine, it was seldom to do reduplication because the authors wanted to make the reader understand easy about the texts.

\section{CONCLUSION}

Based on the result of this study, the writer concludes that there are five forms of code mixing that used in Aneka Yess! magazine in writing process, especially in "Pals Issue" rubric, they are the code mixing of word insertion, code mixing of phrase insertion, code mixing of reduplication insertion, code mixing of idiom/expression insertion, and code mixing of clause insertion. Dealing with the finding of the types of English code mixings used by the editorial staffs of Aneka Yess! magazine, it shows that the code mixings in word insertion is most frequently used by the writer rather than the other types of code mixings, while the most rarely used is code mixing in reduplication insertion.

\section{ACKNOWLEDGEMENT}

The author wanted to thank to all parties who helped the researcher to finish this research. Those were family and my study program, namely English language education study program. 


\section{REFERENCES}

Ansar, F.A. (2017). Code Switching and Code Mixing in Teaching Learning process. English Education: Jurnal Tadris Bahasa Inggris. 10 (1). 29-45.

Astuti, F.F. (2017). A Study on Code Mixing Found in Perahu Kertas Novel by Dewi Lestari. Published Thesis. Surakarta: IAIN Surakarta.

Bar, K \& Hossain, D. (2015). A Case Study in Code-Mixing among Jahangirnagar University Students. International Journal of English and Literature. 6(7). 123-139.

Dijk, A.T. (1985). Handbook of Discourse Analysis. Academic Press London. Retrieved on 12

fromhttp://www.discourses.org/OldArticles/Semantic\%20discourse\%20analysis.pdf $\backslash$

Callhavid. (2010). Code mixing or code switching. http;/callhavid.wordpress.com.

Hartini. (2010). Code Mixing by Muna Language Speakers Residing in Kendari. Unpublished Thesis. Kendari: Haluoleo University.

McManis, C., Stollenwerk, D., Sheng, Z. Z., (1987). Language Files: Materials for An Introduction to Language. The Ohio State University, Department of Lingustics.

Mukti, T.W.P \& Muljani, R. (2016). Code Switching in the instructions of English Language Education Study Program Lecturers. LLT Journal. 19 (1), 46-60.

Mustikawati, D.A. (2018). Code-Mixing and Code Switching in the Process of Learning. REGISTER. 36-80.

Neergaard MA., Olesen F., Andersen RS., Sondergaard J. (2009). Qualitative description - the poor cousin of health research? BMC Medical Research Methodology. 9, 52.

Ratnawati, S. \& Mujiyanto, Y. (2015). Code Switching Used in Conversations by an American Student of the Darmasiswa Program. Language Circle. X(1). 29-35.

Siregar, N., Rasyidah, U., Niati, B. (2016). A Descriptive Analysis of Code Mixing in Facebook Social Networking at Eight Semester Students' of English Study Program of Pasir Pengaraian. Published Thesis. Universitas Pasir Pangaraian.

Soewito. (1985). Sosiolinguistik: Pengantar Awal. Surakarta: Sebelas Maret University.

Sugiyono. (2009). Metode penelitian kualitatif dan kuantitatif. Alfabeta.

Sullivan-Bolyai S., Bova C., Harper D. (2005). Developing and refining interventions in persons with health disparities: the use of qualitative description. Nursing Outlook. 53(3), 127-133.

Suparti \& Gunawan, Y.I. (2018). An Analysis of Code Mixing in a Bilingual Language Acquisition. Globish (An English-Indonesian Journal for English, Education and Culture).7(1). 63-81.

Syafrizal \& Sari, A.R. (2017). Code Mixing in Students' Twitter Status at Sultan Ageng Tirtayasa University In Banten, Indonesia. European Journal of Foreign Language Teaching. 2(1). 117-134.

Thomas, L. (1993). Beginning Syntax. Blackwell: Oxford UK \& Cambridge USA.

Yee Ho, J.W. (2007). Code-Mixing: Linguistic Form and Socio-Cultural Meaning. The International Journal of Language, Society and Culture. Retrieved on $6^{\text {th }}$ November 2010 from: http://www.educ.utas.edu.au/users/tle/JOURNAL/issues/2007/21-2.pdf

Yuliana, N., Luziana, A.R., \& Sarwendah, P. (2015). Code-Mixing and Code Switching of Indonesian Celebrities: Comparative Study. Jurnal Lingua Cultura. 9(1). 47-54. 